\title{
Addis Birhan Wendoch ('New Light Boys'): Working with boys and young men to create healthier futures
}

\author{
Woldemariam Girma \\ Population Council \\ Diane Rubino \\ Population Council \\ Annabel Erulkar \\ Population Council \\ Worku Ambelu \\ Population Council \\ Ayenechew Kerie
}

Follow this and additional works at: https://knowledgecommons.popcouncil.org/departments_sbsr-pgy

Part of the Demography, Population, and Ecology Commons, Family, Life Course, and Society Commons, Gender and Sexuality Commons, Gender Equity in Education Commons, and the International Public Health Commons

How does access to this work benefit you? Let us know!

\section{Recommended Citation}

Girma, Woldemariam, Diane Rubino, Annabel Erulkar, Worku Ambelu, and Ayenechew Kerie. 2012. "Addis Birhan Wendoch ('New Light Boys'): Working with boys and young men to create healthier futures," program brief. Addis Ababa: Population Council. 
ADDIS BIRHAN WENDOCH

("NEW LIGHT BOYS")

WORKING WITH BOYS AND YOUNG MEN

TO CREATE HEALTHIER FUTURES

BY WOLDEMARIAM GIRMA, DIANE RUBINO, ANNABEL ERULKAR, WORKU AMBELU, AND AYENECHEW KERIE

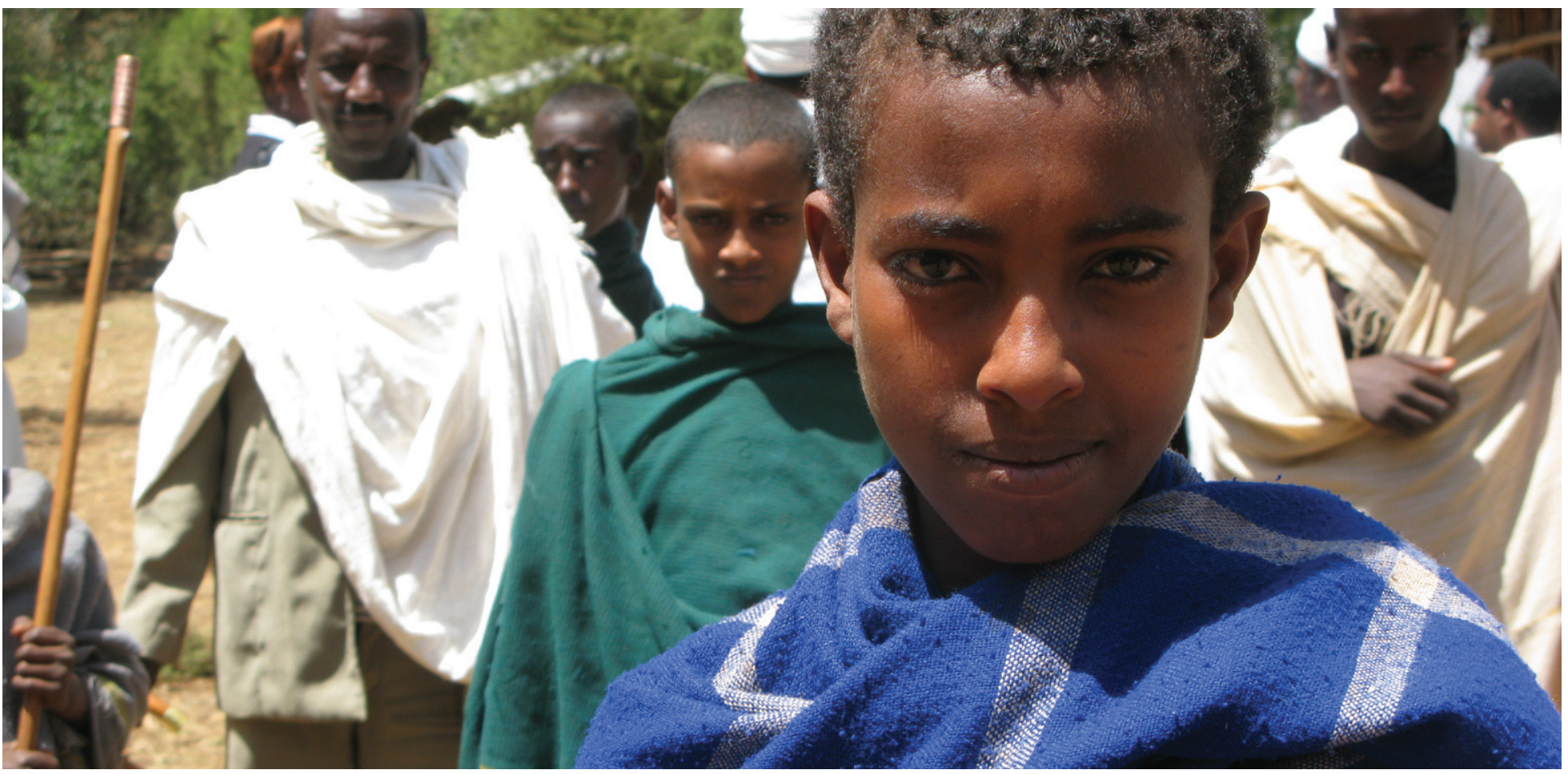

The Addis Birhan Wendoch program (Amharic for "New Light Boys") helps out-of-school boys and young men navigate toward a healthier future by providing them with trained, compassionate mentors and safe environments in which they can find the support needed to share ideas and take positive actions. Through frank and open discussions, boys have the opportunity to get the facts on a range of essential topics from financial literacy to reproductive health issues, including HIV/AIDS and family planning. Mentors share strategies for building vital interpersonal skills, such as communication, self-esteem, and respect. Addis Birhan Wendoch participants also reflect on serious social concerns that are widely prevalent yet rarely discussed in a meaningful way, including violence and substance abuse. Boys report changed behavior and attitudes after participating in Addis Birhan Wendoch-and their mentors agree with these optimistic assessments. 
A dolescence is accompanied by a host of new and positive behavioral, physical, psychological, and social developments. During this time period, young people are also increasingly exposed to, and may begin experimenting with, alcohol and/or illegal drugs, risky sexual behaviors, and violence.

A Population Council study in seven regions of Ethiopia showed that boys are less likely than girls to discuss sex, violence, and marriage with their parents. Conversely, boys are more likely to experience beatings and physical violence from their parents, male friends, or teachers, compared with females (Erulkar et al. 2010). In the same study, boys were more likely than girls to be regular users of drugs and alcohol. Another study, which took place in Bahir Dar, Ethiopia, demonstrated that out-of-school boys who used alcohol and drugs were more likely to be involved in high-risk sexual behavior compared with nonusers (Alemu et al. 2007). The probability of sex was also six times higher among those chewing khat. ${ }^{1}$

Evidence from the developing world suggests that a substantial proportion of unmarried men report multiple sexual partnerships (Singh and Bankole 2001). Moreover, researchers in South Africa also found that simultaneous multiple partnerships were more likely among out-of-school boys compared with those in school (Hargreaves et al. 2008).

Despite the tremendous need for guidance and support among out-of-school boys and young men in Ethiopia, reaching them with life-enhancing initiatives is particularly difficult. Like the generations of men before them, boys have traditionally been excluded from programs providing information on family planning, sexuality, and parenthood. Without this essential knowledge, the ability of these boys to reach their full potential-as individuals, community members, husbands, and fathers-is seriously impaired. Targeted interventions for boys and young men have the potential to provide a supportive forum to change attitudes about gender relations and violence, and to improve family and other social relationships as well as overall health and well-being.

\section{THE ADDIS BIRHAN WENDOCH PROGRAM}

In response to the particular needs of out-of-school boys and young men, the Population Council and the Ethiopian Ministry of Women, Children, and Youth Affairs designed Addis Birhan Wendoch to impart life skills and promote gender-equitable, nonviolent, and healthy behaviors among boys and young men aged 10 to 24 . Since 2010, the program has been implemented in ten urban and peri-urban areas of Amhara and Tigray regions, and Addis Ababa, in collaboration with the Amhara Regional Bureau of Women, Children, and Youth Affairs; the Tigray Regional Bureau of Sport and Youth; and Hiwot Ethiopia, a local nongovernmental organization.

Sixty male mentors aged 22 to 36 with at least ten years of education were recruited from program communities and trained using a curriculum specifically developed to meet the needs of out-of-school boys and young men. The curriculum was adapted from successful programs for boys in other countries, with themes such as life skills, financial literacy, HIV/AIDS and other reproductive health issues, nonviolent and caring relationships, and substance abuse. Illustrations are used as teaching aids given the high rate of illiteracy among participants. Once training is completed, mentors identify beneficiaries by going from house to house in their neighborhoods seeking interested young men to form groups of 25 to 30 participants. Local Ministry

We were more than twenty [boys] and I thought the discussion might be about something one does not share publicly. But after some time, we [the participants] understood each other and discussed everything openly. I had assumed that, as a boy, I shouldn't discuss these issues openly with anybody.

-POOL HALL ATTENDANT, AGE 18, 5 YEARS OF EDUCATION 
offices and "kebele" officials provide "safe spaces" where the boys can gather for learning, mentoring, and relationship-building.

\section{THE BOYS AND YOUNG MEN OF ADDIS BIRHAN WENDOCH}

Nearly 10,000 boys have been enrolled in the program since early 2010 . The majority of beneficiaries (46\%) are aged 15 to 19 , with an average age of 17. More than one-quarter of the beneficiaries have never attended school, and $56 \%$ have had only one to four years of education (Table 1). Nearly half of the boys (43\%) are heads of their own households and live away from their parents. Forty-nine percent are working as daily laborers, and 35\% are unemployed.

TABLE 1 Characteristics of Addis Birhan Wendoch participants, 2010-12 $(n=9,262)$

\begin{tabular}{lc}
\hline & Percent \\
\cline { 2 - 2 } Age & \\
$10-14$ & 26.6 \\
$15-19$ & 46.1 \\
$20+$ & 27.3 \\
Mean age (years) & 17.0 \\
Years of schooling & \\
None & 27.2 \\
$1-4$ & 55.8 \\
$5-8$ & 17.0 \\
\hline
\end{tabular}

\section{PROGRAM EVALUATION DOCUMENTS EVIDENCE OF CHANGE}

Qualitative studies and regular monitoring of the program suggest that participants are changing. Some of the behavioral changes observed are a greater awareness of gender equality and the dangers of drug use/ alcohol consumption, and improved communication and relationships. The boys report they have stopped abusing drugs and alcohol, and they have changed the way they manage their finances, generally saving more money. They also articulate a new respect for themselves and others. Interviews with their mentors confirm that they, too, observe changes in the boys.
Before joining the program, I was addicted to drugs and alcohol and no one in my community had a positive view of me. I did not respect people or community values. After participating in the boys' program, I gave up my addictions and started to respect my mother and community members. I also got tested for HIV and developed the habit of saving money.

-DAILY LABORER, AGE 24, 6 YEARS OF EDUCATION

I like the program because it speaks to people like me who do not typically learn about many of these issues. It helped me improve my financial management and communication skills, stop chewing khat, and develop respect for my elders and peers.

-SHOESHINER, AGE 17, 5 YEARS OF EDUCATION

Following participation in the program, I developed self-esteem and a sense of honor within myself. I started to respect the ideas of others and can now openly discuss many topics. I now have respect, love, and healthy relationships with neighbors and peers.

-DAILY LABORER, AGE 19, 8 YEARS OF EDUCATION

I am proud to be a mentor and to see the reduction of violence and improved parent-child relationships in our community as a result of the Addis Birhan boys' program. 10 YEARS OF EDUCATION 


\section{NEXT STEPS}

Additional research includes a longitudinal survey conducted in Mekele, Tigray Region, to measure the changes associated with the boys' program. Remaining rounds of the survey will be completed in 2013.

\section{NOTE}

1 Khat is a stimulant drug native to East Africa.

\section{REFERENCES}

Alemu, H., D.H. Mariam, K.A. Belay, and G. Davey. 2007. "Factors predisposing out-of-school youths to HIV/ AIDS-related risky sexual behaviour in northwest Ethiopia," Journal of Health Population and Nutrition 25(3): 344-350.
Erulkar A., A. Ferede, W. Ambelu, et al. 2010. Ethiopia Young Adult Survey: A Study in Seven Regions. Addis Ababa, Ethiopia: Population Council.

Hargreaves, J., L. Morison, J. Kim, et al. 2008. "The association between school attendance, HIV infection and sexual behavior among young people in rural South Africa," Journal of Epidemiology and Community Health 62(2): 113-119.

Singh, S. and A. Bankole. 2001. "Gender differences in the sexual and contraceptive behavior of young people: Sub-Saharan Africa, Latin America and the Caribbean." Paper presented at the IUSSP conference, Salvador, Brazil.

\section{ACKNOWLEDGMENTS}

The authors would like to thank Sarah Engebretsen for comments on earlier versions of this program brief.

$\begin{array}{lll}\text { For more information, contact: } & & \\ \text { ANNABEL ERULKAR } & \text { GEBEYEHU MEKONNEN } & \text { SISAY MELLESE } \\ \text { Country Director } & \text { Chief of Party } & \text { Regional Manager } \\ \text { Population Council } & \text { Population Council } & \text { Population Council } \\ \text { P.O. Box 25562, Code 1000 } & \text { P.O. Box 25562, Code 1000 } & \text { Abyssinia Bank Building } \\ \text { Addis Ababa, ETHIOPIA } & \text { Addis Ababa, ETHIOPIA } & \text { Bahir Dar, ETHIOPIA } \\ \text { aerulkar@popcouncil.org } & \text { gmekonnen@popcouncil.org } & \text { smellese@popcouncil.org }\end{array}$

For additional resources, visit www.popcouncil.org

The Population Council confronts critical health and development issues-from stopping the spread of HIV to improving reproductive health and ensuring that young people lead full and productive lives. Through biomedical, social science, and public health research in 50 countries, we work with our partners to deliver solutions that lead to more effective policies, programs, and technologies that improve lives around the world. Established in 1952 and headquartered in New York, the Council is a nongovernmental, nonprofit organization governed by an international board of trustees. 